\title{
PERSAINGAN USAHA TIDAK SEHAT DI INDONESIA MENURUT HUKUM EKONOMI ISLAM DAN UNDANG-UNDANG NOMOR 5 TAHUN 1999 TENTANG LARANGAN MONOPOLI DAN PERSAINGAN USAHA TIDAK SEHAT
}

\author{
Maya Meilia \\ Dosen Sekolah Tinggi Ekonomi dan Bisnis Islam \\ maya@stebilampung.ac.id \\ Darania Anisa \\ Dosen Sekolah Tinggi Ekonomi dan Bisnis Islam \\ darania.anisa@stebilampung.ac.id
}

\section{ABSTRAK}

Pertumbuhan dunia usaha di Indonesia patut dibanggakan. Di berbagai sektor usaha telah menunjukkan perkembangan yang cukup pesat, baik sektor industri maupun jasa, sehingga pada gilirannya muncul persaingan yang seharusnya dipandang sebagai hal positif, dimana dengan adanya persaingan itu sendiri para pelaku usaha akan berlomba-lomba untuk terus memperbaiki produk ataupun jasa yang dihasilkan sehingga pelaku usaha terus menerus melakukan inovasi dan berupaya keras memberi produk atau jasa yang terbaik untuk para konsumen. Menurut hasil penelitian bahwa persaingan usaha menurut hukum ekonomi Islam merupakan kompetisi yang diperbolehkan, asalkan persaingan usaha itu dilaksanakan secara sehat, akan tetapi apabila persaingan usaha yang dilaksanakan itu bersifat monopolistik dalam rangka mengambil keuntungan, maka ekonomi Islam melarangnya. Hal ini disebabkan karena ekonomi Islam memberikan garisan bahwa persaingan usaha harus dilakukan secara sehat (fair play) dengan prinsip kejujuran (honesty), keterbukaan (transparancy), dan keadilan (justice). Sedangkan menurut Undang-Undang No. 5 Tahun 1999, persaingan usaha 
merupakan persaingan yang diperbolehkan, akan tetapi apabila persaingan antar pelaku usaha dalam menjalankan kegiatan produksi dan atau pemasaran barang dan atau jasa yang dilakukan dengan cara tidak jujur atau melawan hukum atau menghambat persaingan usaha, maka menurut ketentuan Pasal 17 ayat (1) Undang-Undang No. 5 Tahun 1999, persaingan usaha tersebut dilarang.

Kata Kunci: Persaingan Usaha Tidak Sehat, Hukum Ekonomi Islam, UU No. 5 Tahun 1999.

\section{A. Pendahuluan}

Pasar merupakan tempat bertemunya antara pedagang dan penjual. Dalamkehidupan nyata, sukar ditemui pasar yang didasarkan pada mekanisme persaingan yang sempurna, namun persaingan dianggap sebagai suatu hal yang esensial dalam ekonomi pasar. Oleh karena dalam keadaan nyata yang kerap terjadi adalah persaingan tidak sempurna. Persaingan yang tidak sempurna terdiri dari persaingan monopolistik dan oligopoli.

Persaingan memberikan keuntungan kepada para pelaku usaha maupun kepada konsumen. Dengan adanya persaingan maka pelaku usaha akan berlomba-lomba untuk terus memperbaiki produk ataupun jasa yang dihasilkan sehingga pelaku usaha terus menerus melakukaninovasi dan berupaya keras memberi produk atau jasa yang terbaikbagi konsumen. Persaingan akan berdampak pada efisiensinya pelakuusaha dalam menghasilkan produk atau jasa. Disisi lain dengan adanyapersaingan maka konsumen sangat diuntungkan karena merekamempunyai pilihan dalam membeli produk atau jasa tertentu denganharga yang murah dan kualitas baik.

Ada beberapa asumsi yang menjadi dasar untuk menentukan adanya persaingan usaha yang mengakibatkan monopoli. Pertama, apabila pelaku usaha mempunyai pengaruh untuk menentukan harga. Kedua, pelaku usaha tidak merasa perlu untuk menyesuaikan diri terhadap pesaing dan terakhir, adanya "entry barrier" bagi pelaku usaha yang ingin masuk dalam pasar yang sudah dimonopoli oleh pelaku usaha (Michael-Kantz dan Harveey S Rosen: 1994, 432-433).

Dibeberapa negara, hukum persaingan dikenal dengan istilah, "Antitrust Laws" atau antimonopoli. Di Indonesia istilah yang sering 
digunakan adalah hukum persaingan atau anti monopoli. Di Indonesia hukum anti monopoli diatur dalam Undang-undang Nomor 5 Tahun 1999 tentang larangan prakek monopoli dan persaingan usaha tidak sehat. Undang-undang ini merupakan pengaturan secara khusus dan komprehensif yang berkaitan dengan persaingan antar pelaku usaha.

Sejarah pertumbuhan perekonomian Indonesia menunjukkan bahwa iklim bersaing di Indonesia belum terjadi sebagaimana yang diharapkan, dimana Indonesia telah membangun perekonomiannya tanpa memberikan perhatian yang memadai untuk terciptanya sebuah struktur pasar persaingan (Agus Maulana: 2000, 4). Khususnya pada masa Orde Baru dimana pada waktu itu terjadi kemandekan sistem persaingan dalam dunia usaha, akibat corak kekuasaan Orde Baru yang sangat mementingkan kelompok dan kronikroninya agar mendapatkan keutungan sistem pasar yang monopolistik. Para ahli ekonomi mengatakan bahwa monopoli terjadi bilamana output seluruh industri diproduksi dan dijual oleh satu perusahaan, yang dinamakan monopolis atau perusahaan monopoli.

Secara sederhana dapat dikatakan bahwa monopoli adalah suatu pasar tanpa persaingan, tetapisebaliknya monopoli dapat juga diperoleh melalui kemampuanusaha, kejelian terhadap bisnis yang tinggi, sehingga pelaku usaha dapat mengelola usahanya pada tingkat efisiensi yang tinggi yang akan menjadikan perusahaannya dapat tumbuh dengan pesat, yaitu dengan cara menawarkan produk kombinasi kualitas dan harga sesuai yang diinginkan oleh konsumen sehingga pangsa pasarnya dapat bertambah dengan cepat dan secara alamiah dapat merebut pangsa pasar yang luas. Dengan adanya pangsa pasar yang luas untuk suatu produk sejenis maka akan dapat terjadi monopoli alamiah dalam suatu pasar.

Monopoli adalah situasi pengadaan barang dagangan tertentu (di pasar local atau nasional) sekurang-kurangnya sepertiga dikuasai oleh satu orang atau satu kelompok, sehingga harganya dapat dikendalikan (Kartika dan Simangunsong: 2007, 170). Sedangkan menurut ketentuan Pasal 1 butir 1 Undang-Undang Nomor 5 tahun 1999 tentang Monopoli dan Persaingan Usaha Tidak Sehat menjelaskan bahwa monopoli adalah "penguasaan atas produksi dan atau pemasaran barang dan atau atas penggunaan jasa tertentu oleh satu pelaku usaha atau satu kelompok pelaku usaha”. 
Agus Maulana (2000: 33) menjelaskan bahwa "Pasar monopoli adalah suatu bentuk pasar dimana hanya terdapat satu perusahaan saja dan perusahaan ini menghasilkan barang yang tidak mempunyai substitusi atau barang pengganti”.Sedangkan menurut Peter Mahmud Marzuki (2001: 512) yang mengatakan bahwa monopoliyang dilarang oleh Undang-undang adalah monopoli yang menyebabkan terjadinya penentuan pasar, pembagian pasar dan konsentrasi pasar.

Munculnya persaingan menjadikan setiap pelaku pasar dituntut untuk terus menemukan metode produksi yang baru untuk memperbaiki kualitas dan harga barang maupun jasa yang dihasilkannya, sehingga terciptalah efisiensi ekonomi, yang berarti pelaku usaha dapat menjual barang dengan harga yang wajar. Hal ini akan sangatmenguntungkan bagi konsumen, karena dapat menikmati barang atau jasa yang tinggi kualitasnya dengan harga yang seimbang.

Hukum persaingan diciptakan dalam rangka mendukung terbentuknya sistem ekonomi pasar, agar persaingan antar pelaku usaha dapat tetap hidup dan berlangsung secara sehat, sehingga konsumen dapat terlindungi dari ajang ekploitasi bisnis.Meskipun persaingan usaha sebenarnya merupakan urusan antar pelaku usaha, namun untuk dapat terciptanya aturan main dalam persaingan usaha, maka pemerintah perlu ikut campur tangan untuk melindungi konsumen. Karena bila hal ini tidak dilakukan maka tidak menutup kemungkinan akan terjadi persengkongkolan (kolusi) antar pelaku bisnis yang akan menjadikan inefisiensi ekonomi, yang pada akhirnya konsumenlah yang akan menanggung beban yaitu membeli barang atau jasa dengan harga dan kualitas yang kurang memadai.

Di Indonesia, pada tanggal 5 Maret 1999 telah diundangkan Undangundang Republik Indonesia Nomor 5 tahun 1999 tentang Larangan Praktek Monopoli dan Persaingan Usaha Tidak Sehat. Pasal 3 Undang-undang tersebut menyatakan bahwa tujuan pembentukan Undang-undang ini adalah untuk: Menjaga kepentingan umum dan meningkatkan efisiensi ekonomi nasional sebagai salah satu upaya untuk meningkatkan kesejahteraan rakyat;Mewujudkan iklim usaha yang kondusif melalui persaingan usaha yang sehat sehingga menjamain adanya kepastian kesempatan berusaha yang sama bagi pelaku usaha besar, pelaku usaha menengah dan pelaku usaha kecil; Mencegah praktek monopoli atau praktek usaha tidak sehat yang 
ditimbulkan oleh pelaku usaha; dan Terciptanya efektifitas dan efisiensi dalam kegiatan usaha.

Istilah monopoli dan persaingan usaha tidak sehat dalam terminologi Islam tidak ditemukan secara konkrit namun dalam Islam terdapat satu ungkapan yang disinyalir (hampir mirip) dengan monopoli yaitu al-Ihtikar. Menurut Hukum Islam, Ikhtikar diartikan sebagai suatu praktik atau proses monopoli atas supply dengan tujuan untuk mendapatkan keuntungan tertentu.

Secara bahasa, al-Ihtikar secara etimologi dapat diartikan dengan: Perbuatan menimbun, pengumpulan (barang-barang) atau tempat untuk menimbun. Dalam kajian fikih al-Ihtikar bermakna menimbun atau menahan agar terjual (Munawir: 1994, 307). Sedangkan menurut Adimarwan (2000: 154) bahwa al-ikhtikar adalah mengambil keuntungan di atas keuntungan normal dengan cara menjual lebih sedikit barang untuk harga yang lebih tinggi, atau istilah ekonominya disebut dengan monopoly's rent.

Adapun al-Ihtikar secara terminologis adalah menahan (menimbun) barang-barang pokok manusia untuk dapat meraih keuntungan dengan menaikkan harganya (Qasim: 1986, 75). Sedangkan menurut Aziz Salim (tt.: 56) menjelaskan bahwa ikhtkar adalah "Penyimpanan barang dagangan oleh penjual makanan untuk menunggu melonjaknya harga dan penjualannya ketika harga melonjaknya, yang menimbun memperoleh keuntungan besar, sedang masyarakat dirugikan".

Ketentuan dalam al-Qur'an secara langsung tidak menyebutkan mengenai al-Ihtikar (Monopolistic rent). Tetapi ada ayat yang menyebutkan mengenai praktek penimbunan emas dan perak, sebagaimana terdapat di dalam al-Qur'an Surat al-Imran ayat 108. Walaupun tidak ditemukan secara jelas dalam al-Qur'an tentang Monopolitetapi ia mempunyai hubungan erat dengan riba, dimana riba ini sangat dilarang. Karena di dalam riba terdapat unsur zulmun (menganiaya) orang lain diakibatkan karena ketidakmampuan peminjam untuk membayarkan utangnya tepat waktu maka secara otomatis harga menjadi naik melebihi pokok pinjamannya dan hal ini memberatkan yang mengakibatkan sipeminjam teraniaya dan secara terpaksa harus membayarkan tambahan modal tersebut. 
Sementara ihtikar walaupun secara implisit, juga menagandung zulmun (menzhalimi) dan masyarakat akan merasakan akibat fatalnya. Sebab al-Ihtikar bertujuan untuk mencari keuntungan yang lebih banyak, dengan menimbun barang yang beredar di pasaran dapat mengakibatkan kelangkaan dan tentunya akan terjadi kenaikan harga secara otomatis di atas normal. Sehingga masyarakat yang biasanya tidak kekurangan barang dan dapat membelinya sesuai kehendaknya tanpa merasakan kesulitan, namun karena akibat ihtikar tersebut mereka jadi kekurangan barang dan sulit untuk menjangkau harga agar dapat memenuhi kebutuhan mereka, namun karena sudah terdesak akan kebutuhan pokok dan hidup sehari-hari barang yang langka tersebut akhirnya dibeli juga walaupun terpaksa.

Kegiatan persaingan dalam dunia usaha yang tidak sehat yang mengakibatkan terjadinya monopoli inilah yang membuat menarik peneliti untuk mengkaji lebih dalam terutama menggunakan kerangka teori Hukum Ekonomi Islam dan Undang-Undang Nomor 5 Tahun 1999 tentang Larangan Monopoli dan Persaingan Usaha Tidak Sehat, dan terkait dengan prospek penerapan UU No.5 Tahun 1999 sebagai upaya pencegahan terhadap persaingan usaha di Indonesia yang bersifat monopolistik.

\section{B. Kerangka Teoritis}

Persaingan usaha merupakan prasyarat ekonomi pasar bebas yang memberikan empat keuntungan dalam pembangunan ekonomi Indonesia. Yaitu, terciptanya harga yang kompetitif, peningkatan kualitas hidup oleh karena inovasi yang terus-menerus, mendorong dan meningkatkan mobilitas masyarakat, serta adanya efisiensi baik efisiensi produktif maupun alokatif. Namun demikian, keuntungan tersebut dapat kita nikmati hanya jika terdapat faktor-faktor penentu, yaitu: stabilitas dan prediktabilitas hukum, keadilan, pendidikan, dan kemampuan aparat penegak hukum.

Pengertian dan pemahaman yang salah akan persaingan dan pasar bebas mengakibatkan timbulnya sikap skeptis para pembuat kebijakan dan penegak hukum ketika Undang-undang ini disahkan. Pertanyaan yang timbul adalah dapatkah Undang-undang antimonopoli ini memberikan manfaat bagi masyarakat Indonesia mengingat selama ini Indonesia mengalami pembangunan dengan sistem ekonomi yang diperintah dan terencana. 
Selain itu persaingan selalu dikaitkan dengan individualisme yang bertolak belakang dengan kultur masyarakat yang komunal dimana segala sesuatunya dilakukan atas dasar kekeluargaan dan gotong-royong. Hal ini dikuatkan oleh Pasal 33 Undang-undang Dasar 1945 bahwa cabang-cabang produksi yang penting dan menguasai hajat hidup orang banyak dikuasai oleh negara. Ayat lainnya menyatakan perekonomian Indonesia dilandaskan pada demokrasi ekonomi kerakyatan. Undang-undang No. 5 Tahun 1999 tentang Larangan Praktek Monopoli dan Persaingan Usaha Tidak Sehat kini tengah memasuki arena penegakan hukum dan diharapkan mampu memberikan manfaat bagi masyarakat serta menciptakan efisiensi bagi pelaku usaha, yang tentu saja akan membawa kesejahteraan bagi konsumen. Adanya sikap skeptis dapat menjadi hambatan bagi terwujudnya tujuan yang ingin dicapai Undang-undang antimonopoli ini mengingat ada relevansi yang kuat antara hukum dengan pembangunan ekonomi (David M. Trubeck: 1972, 6). Hukum merupakan alat rekayasa sosial yang dapat mendorong pertumbuhan ekonomi suatu negara. Hukum persaingan usaha di Indonesia dapat menjalankan tugasnya sebagai alat rekayasa sosial apabila terdapat keadaan yang cukup kondusif, yaitu stabilitas, prediktabilitas, keadilan, pendidikan, dan kemampuan aparat penegak hukum. Dengan demikian hukum persaingan usaha mampu menempatkan dirinya tidak saja sebagai alat rekayasa sosial namun juga sebagai tool of economic development.

Persaingan dan usaha yang begitu luas bila dapat diterjemahkan kedalam sebuah pemahaman yang komprehensif, pengertian yang dimaksud juga sangat beragam. Dalam Kamus Besar Bahasa Indonesia, bisnis diartikan sebagai usaha dagang, usaha komersil di dunia perdagangan, dan bidang usaha (Yusanto dan Wijajakusuma: 2002, 6). Sedangkan dalam bahasa arab persaingan bisnis berasal dari kata al-ajruyang berarti menurut bahasa adalah al-imadi yang artinya dalam bahasa Indonesia gaji atau upah(Atabik Ali, Achmad Zuhdi Muhdlor: 1998, 1278).

Berbicara tentang persaingan usaha tentunya perlu mengetahui pengertian persaingan itu sendiri. Persaingan dari kata dasar "saing" yang berati berlomba atau (mengatasi, dahulu mendahului), dengan kata lain yakni usaha untuk memperhatikan keunggulan masing-masing yang dilakukan perseorangan atau badan hukum dalam bidang perdagangan, produksi, pertahanan dan sebagainya. 
Islam sebagai suatu sistem hidup (way to life) dan manusia adalah khalifah di muka bumi, Islam memandang bumi dengan segala isinya merupakan amanah Allah SWT. kepada sang khalifah agar digunakan sebaikbaiknya bagi kesejahteraan bersama. Untuk mencapai tujuan suci ini, Allah memberikan perumus melalui para rasul-Nya. Petunjuk tersebut meliputi segala sesuatu yang dibutuhkan manusia baik aqidah, akhlak, maupun syariah. Dua komponen pertama, aqidah dan akhlak bersifat konstan, keduanya tidak mengalami perubahan apapun dengan berbedanya waktu dan tempat. Adapun syariah senantiasa berubah sesuai dengan kebutuhan dan taraf peradaban umat yang berbeda-beda sesuai dengan masa rasul masingmasing (Antonio: 2001, 3-4), termasuk dalam dunia bisnis. Al-Qur'an memberi pentunjuk agar dalam bisnis tercipta hubungan yang harmonis, saling ridha, tidak ada unsur eksploitasi.

Syed Nawab Haidar Naqvi dalam Mujahidin (2005: 123) memaparkan empat aksioma etika ekonomi, yaitu, tauhid, keseimbangan (keadilan), kebebasan dan tanggung jawab. Tauhid merupakan wacana teologis yang mendasari segala aktivitas manusia, termasuk dalam berbisnis. Tauhid menyadarkan manusia sebagai makhluk ilahiyah atau makhluk yang bertuhan.

Kepemilikan individu yang tak terbatas, sebagaimana dalam sistem kapitalis, tidak dibenarkan. Dalam Islam, Harta mempunyai fungsi sosial yang kental. Kebebasan, berarti manusia sebagai individu dan kolektivitas, mempunyai kebebasan penuh untuk melakukan aktivitas bisnis. Dalam ekonomi, manusia bebas mengimplementasikan kaidah-kaidah Islam. Karena masalah ekonomi, termasuk aspek mu'amalah, bukan ibadah, maka berlaku padanya kaidah umum, "semua boleh kecuali yang dilarang". Yang tidak boleh dalam Islam adalah ketidakadilan dan riba. Dalam tataran ini kebebasan manusia sesungguhnya tidak mutlak, tetapi merupakan kebebasan yang bertanggung jawab dan berkeadilan. Pertanggungjawaban, berarti, bahwa manusia sebagai pelaku bisnis, mempunyai tanggung jawab moral kepada Tuhan atas perilaku bisnis. Harta sebagai komoditi bisnis dalam Islam, adalah amanah Tuhan yang harus dipertanggungjawabkan di hadapan Tuhan (Algaoud \& Lewis : 2005, 42).

Sedangkan pedoman bisnis menurut Imam Ibnu Taymiyyah dalam kitab Al Hisbah antara lain adalah: Pertama, sempurna dalam timbangan 
"Kecelakaanlah bagi orang-orang yang curang, (yaitu) orang-orang yang apabila menerima takaran dari orang lain ia minta dipenuhi. Dan apabila mereka menakar atau menimbang untuk orang lain, mereka mengurangi”. Kedua, hindari penipuan/kecurangan. Ketiga, hindari kontrak bisnis yang tidak sah (illegal). Kontrak yang terkait dengan riba dan judi seperti jual beli spekulatif (bay al-gharar), membeli bayi ternak yang masih dalam kandungan (mulamasa), menawar tinggi untuk menaikkan harga bukan berniat untuk membeli (najas). Keempat, kondisi ketidaksempurnaan pasar.

Selain itu, persaingan dalam pasar dan mekanisme pasar dapat membentuk beberapa jenis pasar. Ada yang disebut dengan pasar persaingan sempurna (perfect competition market), pasar monopoli maupun pasar oligopoli. Persaingan sempurna adalah struktur pasar yang paling ideal karena sistem pasar ini adalah struktur pasar yang akan menjamin terwujudnya kegiatan memproduksi barang dan jasa yang sangat tinggi efisiensinya.

Empat asumsi yang melandasi agar terjadinya persaingan sempurna pada suatu pasar tertentu, yaitu:

1. Pelaku usaha tidak dapat menentukan secara sepihak harga atas produk atau jasa. Adapun yang menentukan harga adalah pasar berdasarkan ekuilibrium permintaan dan penawaran (supply and demand). Dengan demikian, pelaku pasar dalam pasar persaingan sempurna tidak bertindak sebagai price maker melainkan hanya bertindak sebagai price taker.

2. Barang dan atau jasa yang dihasilkan oleh pelaku usaha adalah betul-betul sama (pr(oduct homogeneity).

3. Pelaku usaha mempunyai kebebasan untuk masuk atau keluar pasar (perfect mobility of resources).

4. Konsumen dan pelaku usaha memiliki informasi yang sempurna (perfect information) tentang berbagai hal, diantaranya kesukaan, tingkat pendapatan, biaya dan teknologi yang digunakan untuk menghasilkan barang dan jasa. Selain empat asumsi di atas, Soeharno menambahkan bahwa ciri pasar persaingan sempurna adalah penjual dan pembeli secara individu tidak dapat mempengaruhi harga (price taker). (Robert S. Pindyck and Daniel L. Rubinfel: 1998, 283). 
Tati Suhartati Joesron dan M. Fathorrazi (2012: 153) berpendapat bahwa suatu pasar dapat dikatakan sebagai pasar persaingan sempurna atau perfect competition jika memenuhi syarat sebagai berikut:

a. Terdiri dari banyak penjual dan banyak pembeli. Hal ini menyebabkan perilaku penjual atau pembeli tidak dapat mempengaruhi keadaan pasar, karena ia merupakan bagian kecil dari keseluruhan yang ada di pasar. Seorang penjual atau pembeli dikatakan sebagai pengikut harga (price taker) sehingga harga di pasar bersifat datum, artinya berapapun jumlah barang yang dijual di pasar, harganya akan tetap. Harga pasar ditentukan oleh bekerjanya mekanisme pasar yaitu oleh interaksi antara seluruh penjual dan pembeli yang ada di pasar.

b. Adanya kebebasan untuk membuka dan menutup perusahaan (free entry and free exit). Dalam hal ini tidak ada hambatan yang menghalangi suatu perusahaan untuk memulai usaha baru jika dianggap menguntungkan dan menutup usahanya jika dianggap merugikan, baik secara legal maupun bentuk hambatan lainnya.

c. Barang yang diperjual belikan bersifat homogen. Dalam hal ini barang yang dihasilkan merupakan pengganti yang sempurna terhadap barang yang dihasilkan oleh produsen lain dalam semua segi. Homogenitas barang yang dihasilkan ini ditentukan oleh konsumen dan bukan dilihat dari spesifikasi tekhnis saja.

d. Penjual dan pembeli mempunyai pengetahuan yang sempurna tentang keadaan pasar. Dalam hal ini penjual dan pembeli mempunyai pengetahuan yang sempurna tentang keadaan pasar, yaitu mengetahui tingkat harga yang berlaku di pasar dan perubahan-perubahannya. Adanya inforrmasi yang lengkap tentang pasar (perfect knowledge) ini mengakibatkan: Tidak ada penjual yang menjual dengan harga yang lebih rendah dari harga pasar; Tidak ada pembeli yang membeli dengan harga yang lebih dari harga pasar; Tidak ada sumber daya yang digunakan untuk berproduksi yang kurang menguntungkan daripada yang lain; dan Mobilitas sumber ekonomi yang cukup sempurna.

Monopoli tidak hanya diartikan mencakup struktur pasar dengan hanya ada satu pemasok atau pembeli di pasar bersangkutan, hal mana dikarenakan struktur pasar (yang hanya satu pemasok) jarang sekali terjadi. 
Menurut Pasal 17 ayat 2 Undang-undang nomor 5 Tahun 1999, bahwa pelaku usaha patut diduga atau dianggap melakukan penguasaan atas produksi dan atau pemasaran barang dan atau jasa, jika barang dan atau jasa yang dimaksud belum ada substitusinya, mengakibatkan pelaku usaha lain tidak dapat masuk ke dalam persaingan usaha barang dan atau jasa yang sama, atau saru pelaku usaha atau satu kelompok pelaku usaha menguasai pangsa pasar lebih dari 50 persen terhadap satu jenis barang atau jasa tertentu.

Monopoli dapat terjadi dengan dua cara, yaitu: Monopoli alamiah (natural monopoly) dan monopoli berdasarkan hukum (monopoly by law).Monopoli alamiah terjadi akibat kemampuan seseorang atau sekelompok pelaku usaha yang mempunyai satu kelebihan tertentu, sehingga membuat pelaku usaha lain kalah bersaing, sedangkan monopoli berdasarkan hukum (monopoly by law) adalah monopoli yang berasal dari pemberian negara seperti yang termaktub dalam Pasal 33 UUD 1945, yang selanjuutnya dilindungi oleh peraturan perundang-undangan, misalnya pada Perusahaan Listrik Negara, Pertamina, dan lain sebagainya.

Pasar monopoli adalah suatu bentuk pasar dimana hanya terdapat satu perusahaan saja yang menghasilkan barang yang tidak dipunyai barang pengganti perusahaan, tidak mempunyai barang pengganti yang mirip, tidak terdapat kemungkinan untuk masuk ke dalam industri, dapat menguasai penentuan harga serta promosi iklan kurang diperlukan. Pasar monopli dapar diartikan sebagai suatu model pasar yang mempunyai ciri hanya terdapat satu penjual di pasar, output yang dihasilkan oleh produsen bersifat lain, tidak mempunyai barang pengganti yang sangat dekat, di pasar ada rintangan bagi produsen lain untuk memasukinya (barries to entry).

Pasar monopoli merupakan kebalikan dari pasar persaingan sempurna, sedangkan pasar-pasar lainnya berada di antara keduanya. Faktor-faktor yang memungkinkan untuk dapat terjadi monopoli, adalah:Produsen mempunyai hak paten untuk output yang dihasilkan, seperti hak pengarang, merek dagang, nama dagang, produsen memiliki salah satu sumber daya yang penting dan merahasiakannya atau produsen memiliki pengetahuan yang lain daripada yang lain tentang teknis produksi, pemberian izin khusus oleh pemerintah pada produsen tententu untuk mengelola suatu usaha tertentu, ukuran pasar begitu kecil untuk dilayani lebih dari satu perusahaan yang 
mengoperasikan skala perusahaan optimum, dan produsen menerapkan kebijaksanaan pembatasan harga (limit pricing policy).

Adanya monopoli dapat merusak sifat-sifat efisiensi dari sistem harga persaingan. Hal ini dikarenakan monopoli dapat mempengaruhi harga pasar, perusahaan tersebut mungkin berkepentingan untuk membatasi keluaran dengan tujuan untuk mendapatkan harga yang lebih tinggi daripada yang tersedia dalam harga persaingan (Walter Nicholson: 1999, 204-205).

Menurut perspektif Islam, monopoli (ihtikar) berasal dari kata hakr, yang berarti mengumpulkan dan menguasai barang kebutuhan. Ihtikar digunakan oleh para ahli Fiqh Islam untuk menyatakan hak istimewa untuk mengumpulkan dan menguasai barang kebutuhan dalam upaya mengantisipasi kenaikan harga. Dengan kata lain, ihtikar berarti proses memonopoli produk agar mengakibatkan terjadinya kenaikan harga.

Monopoli atau ihtikar artinya menimbun barang agar yang beredar di masyarakat berkurang, lalu harganya naik. Yang menimbun memperoleh keuntungan besar, sedang masyarakat dirugikan (Basyarahil: tt, 56). Menurut Adimarwan (2002: 73) "Monopoli secara harfiah berarti di pasar hanya ada satu penjual". Hal ini didasarkan pada hadist yang artinya: Dari Sa'id bin Musayyab ia meriwayatkan: Bahwa Ma'mar, ia berkata, "Rasulullah saw. bersabda, 'Barangsiapa menimbun barang, maka ia berdosa'," (HR Muslim (1605).

Berdasarkan hal tersebut, bahwa monopoli seperti yang dijelaskan dalam tersebut merupakan kegiatan yang dilarang dan hukumnya adalah haram, karena perbuatan demikian didorong oleh nafsu serakah, loba dan tamak, serta mementingkan diri sendiri dengan merugikan orang banyak. Selain itu juga menunjukan bahwa pelakunya mempunyai moral dan mental yang rendah.

Para ulama berbeda pendapat tentang hukum ihtikar. Haram secara mutlak (tidak dikhususkan bahan makanan saja), hal ini didasari oleh sabda Nabi Saw bahwa Barangsiapa menimbun maka dia telah berbuat dosa. (HR. Muslim 1605). Menimbun yang diharamkan menurut kebanyakan ulama fikih bila memenuhi tiga kriteria:Barang yang ditimbun melebihi kebutuhannya dan kebutuhan keluarga untuk masa satu tahun penuh. Kita hanya boleh menyimpan barang untuk keperluan kurang dari satu tahun sebagaimana pernah dilakukan Rasulullah Saw; Menimbun untuk dijual, 
kemudian pada waktu harganya membumbung tinggi dan kebutuhan rakyat sudah mendesak baru dijual sehingga terpaksa rakyat membelinya dengan harga mahal; Yang ditimbun (dimonopoli) ialah kebutuhan pokok rakyat seperti pangan, sandang dan lain-lain. Apabila bahan-bahan lainnya ada di tangan banyak pedagang, tetatpi tidak termasuk bahan pokok kebutuhan rakyat dan tidak merugikan rakyat. maka itu tidak termasuk menimbun.

Sedangkan ulama yang memberikan hukum makruh secara mutlak, yaitu dengan alasan bahwa larangan Nabi Saw berkaitan dengan ihtikar adalah terbatas kepada hukum makruh saja, lantaran hanya sebagai peringatan bagi umatnya.Al-Hafidz Ibnu Hajar al-Asqolani berkata:"Imam Bukhori sepertinya berdalil atas bolehnya menimbun/ihtikar dengan (hadits ini), karena Nabi Saw memerintahkan pembeli bahan makanan supaya mengangkutnya terlebih dahulu ke rumah-rumah mereka sebelum menjualnya kembali, dan seandainya ihtikar itu dilarang, maka Rosulullah Saw tidak akan memerintahkan hal itu." (Fathul Bari 4/439-440).

Demikian pula pendapat tentang waktu diharamkannya ihtikar. Ada ulama yang mengharamkan ihtikar setiap waktu secara mutlaku, tanpa membedakan masa paceklik dengan masa surplus pangan, berdasarkan sifat umum larangan terhadap monopoli dari hadits yang sudah lalu. Ini adalah pendapat golongan salaf.

\section{Metode Penelitian}

Jenispenelitian ini adalah jenis penelitian kepustakaan (library research) yaitu; pengumpulan data dan informasi dengan bantuan bermacam-macam materi yang terdapat di ruang perpustakaan (Kartono: 1996, 33). Penelitian kepustakaan dimaksudkan dengan cara mengumpulkan bahan-bahan yang berasal dari buku-buku, artikel-artikel, makalah atau jurnal dan bahan-bahan lainnya yang berkaitan dengan masalah yang diangkat.

Teknik Pengumpulan data yang digunakan dalam penelitian ini melalui pengambilan data dari studi kepustakaan, dengan mengkaji sejumlah literatur seperti peraturan perundang-undangan, buku artikel, makalah, laporan hasil penelitian, majalah dan surat kabar yang berkenaan dengan masalah yang diangkat.

Sumber data dalam penelitian ini adalah sumber data primer dan data sekunder. Adapun data primer dari penelitian ini adalah; 1) Al-qur'an dan 
As-Sunnah serta pendapat para ulama di dalam kitab-kitab fikih yang relevan, 2) Undang - Undang RI Tahun 1945, dan 3) Undang-Undang RI No. 5 Tahun 1999 tentang Larangan Monopoli dan Persaingan Usaha Tidak Sehat. Sedangkan data sekunder yang digunakan dalam penulisan penelitian ini yakni, buku-buku, artikel-artikel dan jurnal serta bahan-bahan bacaan lainnya yang sangat relevan sebagai bahan penunjang di dalam penulisan penelitian ini.

Analisa data sebagai bagian penting dari penelitian, seringkali peneliti menggunakan kutipan-kutipan dari hasil penelitianterdahulu atau mengutip pendapat para ahli dari buku karyailmiah sebagai upaya untuk mempertajam analisa yang akandikerjakan. Data yang diperoleh dari hasil studi pustaka disusunsecara sistematis, sehingga memperoleh gambaran secaramenyeluruh tentang permasalahan yang diteliti. Dari hasil analisa tersebut maka diambillah kesimpulan akhir dari pembahasan penelitian ini.

\section{Hasil Penelitian}

Berbicara persaingan usaha tidak akan terlepas dari kajian pasar. Hal ini disebabkan karena pasar merupakan tempat transaksi munculnya sebuah persaingan usaha antara pelaku usaha. Pelaku usaha sebenarnya merupakan pesaing di antara mereka sendiri kemudian melakukan konsolidasi dan bergabung bersama dalam suatu wadah bisnis atau asosiasi. Asosiasi mengatur tugas dan tanggung jawab anggotanya, juga mengeluarkan peraturan internal yang dapat dikategorikan menghambat perdagangan (misalnya peraturan dasar tentang komisi, masalah diskon, waktu melakukan transaksi, atau jam berusaha) yang dapat dikategorikan sebagai bentuk lain dari hambatan perdagangan (nonprice trade restraint).

Persaingan usaha sendiri dalam kamus manajamen dapat diartikan sebagai suatu kegiatan bersaing/ bertanding diantara pengusaha atau pembisnis yang satu dengan pengusaha lainnya di dalam memenangkan pangsa pasar (share market) dalam upaya melakukan penawaran produk barang dan jasa kepada konsumen dengan berbagai strategi pemasaran yang diterapkan. Persaingan usaha terdiri atas persaingan sehat (healthy competition) dan persaingan gorok leher (cut throat competition).

Menurut teori persaingan sempurna ekonomi klasik, pasar terdiri atas sejumlah produsen dan konsumen kecil yang tidak menentu. Kebebasan 
masuk dan keluar, kebebasan memilih teknologi dan metode produksi, serta kebebasan dan ketersediaan informasi, semuanya dijamin oleh pemerintah. Dalam keadaan pasar seperti ini, dituntut adanya teknologi yang efisien, sehingga pelaku pasar akan dapat bertahan (Muhammad: 2004, 371).

Namun sistem ekonomi seperti ini, dituduh oleh kaum sosialis hanya melindungi pemilik faktor produksi. Sehingga ada tudingan bahwa kaum kapitalis telah membuat keputusan ekonomi yang mengejar kepentingan individu, menekankan tingkat upah yang minimal dan mendorong keuntungan yang sebesar-besarnya, mengkonsetrasikan ekonomi pada sebagian kecil orang saja. Selanjutnya, sistem ekonomi pasar bebas juga telah membawa kepada ketidakstabilan dalam aktivitas ekonomi dan perputaran usaha.

Munir Fuady (1994: 8) menjelaskan bahwa dalam ilmu hukum monopoli, dikenal beberapa sikap monopolistik, yaitu:

1. Mempersulit masuknya para pesaing ke dalam bisnis yang bersangkutan;

2. Melakukan pemasungan (captive) sumber suplai yang penting atau outline distribusi yang penting;

3. Mendapatkan hak paten yang dapat mengakibatkan pihak pesaingnya sulit untuk menandingi produk atau jasa tersebut;

4. Integrasi ke atas atau ke bawah yang dapat menaiki persediaan modal bagi pesaingnya atau membatasi akses pesaingnya kepada konsumen atau supplier;

5. Mempromosikan produk secara besar-besaran;

6. Menyewa tenaga-tenaga ahli yang berlebihan;

7. Pembedaan harga yang dapat mengakibatkan sulitnya bersaing dari pelaku pasar lain;

8. Kepada pihak pesaing disembunyikan informasi tentang pengembagan produk, tentang waktu atau skala produksi;

9. Memotong harga secara drastis; membeli atau mengakuisisi pesaing-pesaing yang tergolong kuat atau tergolong prospektif;

10. Menggugat pesaing-pesaingnya atas tuduhan pemalsuan hak paten, pelanggaran hukum anti monopoli dan tuduhan-tuduhan lainnya. 
Pasar sebagai tempat persaingan usaha merupakan tempat bertemunya penjual dan pembeli yang disana terjadi transaksi. Secara garis besar pasar dapat dibagi menjadi dua, pertama: pasar nyata atau konkrit, atau tempat bertemunya penjual dan pembeli untuk melakukan transaksi jual beli barang atau jasa, misalnya pasar tradisional, kedua; pasar abstrak, merupakan pasar yang penjual dan pembelinya tidak bertemu secara langsung, misalnya pasar bursa komoditi dan bursam saham.

Sebuah negara dengan kebijakan, baik pasar bebas ataupun ekonomi terencana memiliki dasar argumen tersendiri mengapa salah satunya dipilih sebagai landasan kebijakan. Selama lebih dari dua dekade bangsa Indonesia mengalami pembangunan ekonomi dengan sistem ekonomi yang diperintah dan pada akhir 1990-an mengalami transisi ekonomi pada mekanisme pasar adalah hal baru baik bagi pemerintah, para pelaku usaha maupun konsumen. Sistem ekonomi terencana tidak memberikan ruang gerak yang bebas bagi para pelaku usaha dalam berbisnis.

Ekonomi Islam memandang bahwa pasar, negara, dan individu berada dalam keseimbangan (iqtishad), tidak boleh ada sub-ordinat, sehingga salah satunya menjadi dominan dari yang lain. Pasar dijamin kebebasannya dalam Islam. Pasar bebas menentukan cara-cara produksi dan harga, tidak boleh ada gangguan yang mengakibatkan rusaknya keseimbangan pasar. Namun dalam kenyataannya sulit ditemukan pasar yang berjalan sendiri secara adil (fair). Distorasi pasar tetap sering terjadi, sehingga dapat merugikan para pihak.

Pasar yang dibiarkan berjalan sendiri (laissez faire), tanpa ada yang mengontrol, ternyata telah menyebabkan penguasaan pasar sepihak oleh pemilik modal (capitalist) penguasa infrastruktur dan pemilik informasi. Asymetrik informasi juga menjadi permasalahan yang tidak bisa diselesaikan oleh pasar. Negara dalam Islam mempunyai peran yang sama dengan pasar, tugasnya adalah mengatur dan mengawasi ekonomi, memastikan kompetisi di pasar berlangsung dengan sempurna, informasi yang merata dan keadilan ekonomi. Perannya sebagai pengatur tidak lantas menjadikannya dominan, sebab negara, sekali-kali tidak boleh mengganggu pasar yang berjalan seimbang, perannya hanya diperlukan ketika terjadi distorsi dalam sistem pasar.

Konsep makanisme pasar dalam Islam dapat dirujuk kepada hadits Rasululllah Saw sebagaimana disampaikan oleh Anas RA, sehubungan dengan 
adanya kenaikan harga-harga barang di kota Madinah. Dengan hadits ini terlihat dengan jelas bahwa Islam jauh lebih dahulu (lebih 1160 tahun) mengajarkan konsep mekanisme pasar dari pada Adam Smith. Dalam hadits Nabi Muhammad Saw. dijelaskan bahwa: Harga barang dagangan pernah melambung tinggi di Madinah pada zaman Nabi Saw, lalu orang-orang pun berkata:"Wahai Rasulullah, harga barang melambung, maka tetapkanlah standar harga untuk kami. Maka Rasulullah Saw bersabda:"Sesungguhnya Allah lah al-Musa'ir (Yang Maha Menetapkan harga), al-Qabidh, al-Basith, dan arRaziq. Dan sungguh aku benar-benar berharap berjumpa dengan Allah dalam keadaan tidak ada seorang pun dari kalian yang menuntutku dengan kezhaliman dalam masalah darah (nyawa) dan harta". (HR. al-Khomsah kecuali an-Nasa'i dan dishahihkan oleh Ibnu Hibban).

Inilah teori ekonomi Islam mengenai harga. Rasulullah Saw. dalam hadits tersebut tidak menentukan harga. Ini menunjukkan bahwa ketentuan harga itu diserahkan kepada mekanisme pasar yang alamiah impersonal. Rasulullah menolak tawaran itu dan mengatakan bahwa harga di pasar tidak boleh ditetapkan, karena Allah-lah yang menentukannya.

Sungguh menakjubkan, teori Nabi tentang harga dan pasar. Kekaguman ini dikarenakan, ucapan Nabi Saw itu mengandung pengertian bahwa harga pasar itu sesuai dengan kehendak Allah yang sunnatullah atau hukum supply and demand. Menurut pakar ekonomi Islam kontemporer, teori inilah yang diadopsi oleh Bapak Ekonomi Barat, Adam Smith dengan nama teori invisible hands. Menurut teori ini, pasar akan diatur oleh tangantangan tidak kelihatan (invisible hands). Bukankah teori invisible hands itu lebih tepat dikatakan God Hands (tangan-tangan Allah). Oleh karena harga sesuai dengan kekuatan penawaran dan permintaan di pasar, maka harga barang tidak boleh ditetapkan pemerintah, karena ketentuan harga tergantung pada hukum supply and demand. Namun demikian, ekonomi Islam masih memberikan peluang pada kondisi tertentu untuk melalukan intervensi harga (price intervention) bila para pedagang melakukan monopoli dan kecurangan yang menekan dan merugikan konsumen.

Pasar sebagai mekanisme pertukaran barang dan jasa yang alamiah dan telah berlangsung sejak peradaban awal manusia. Islam menempatkan pasar pada kedudukan yang sangat penting dalam perekonomian. Praktik ekonomi pada masa Rasulullah dan Khulafaurasyidin menunjukkan adanya peranan 
pasar yang besar. Rasulullah sangat menghargai harga yang dibentuk oleh pasar sebagai harga yang adil. Beliau menolak adanya suatu price intervenstion seandainya perubahan harga terjadi karena mekanisme pasar yang wajar. Namun, pasar di sini mengharuskanadanya moralitas, antara lain: persaingan yang sehat (fair play), kejujuran (honesty), keterbukaan (transparancy), dan keadilan (justice). Jika nilai-nilai ini telah ditegakkan, maka tidak ada alasan untuk menolak harga pasar.

Selain melarang intervensi harga, ada beberapa larangan yang diberlakukan Rasulullah Saw untuk menjaga agar seseorang tidak dapat melambungkan harga seenaknya seperti larangan menukar kualitas mutu barang dengan kualitas rendah dengan harga yang sama serta mengurangi timbangan barang dagangan. (Karim: 2010, 182).

Berkaitan dengan hal tersebut, menurut Islam negara memiliki hak untuk melakukan intervensi dalam kegiatan ekonomi, baik itu dalam bentuk pengawasan, pengaturan maupun pelaksanaan kegiatan ekonomi yang tidak mampu dilaksanakan oleh masyarakat. Intervensi harga oleh pemerintah bisa karena faktor alamiah maupun non alamiah. Pada umumnya intervensi pemerintah berupa kebijakan dalam regulasi yang berhubungan dengan permintaan dan penawaran dan intervensi dalam menentukan harga. Intervensi dengan cara membuat kebijakan yang dapat mempengaruhi dari sisi permintaan maupun dari sisi penawaran (market intervention) biasanya dikarenakan distorsi pasar karena faktor alamiah. Bila distori pasar terjadi karena faktor non alamiah, maka kebijakan yang ditempuh salah satunya dengan intervensi harga pasar.

Mekanisme pasar, regulasi dan moral harus ada dalam satu kesatuan, satu paket pemikiran. Dengan adanya moral dan harga saja, boleh jadi belum mampu mewujudkan tujuan-tujuan yang diinginkan masyarakat. Maka dari itu, peran efektif negara sebagai mitra, katalisator dan fasilitator, sangat dibutuhkan untuk mewujudkan misi Islam. Berdasarkan hadis di atas telah menekankan perlunya peran-peran tersebut. Al-Qur'an hanya menyediakan norma-norma dan memerintahkan kaum muslimin untuk menjalankan norma-norma itu, dengan harapan kaum muslimin mentaatinya. Namun beberapa dari mereka tidak mau mematuhinya, khususnya manakala moral lingkungan telah rusak. Maka dari itu negara mempunyai peranan penting melalui pendidikan, dorongan dan pencegahan untuk tingkah laku yang 
membahayakan masyarakat seperti kezaliman, kecurangan, penipuan, dan keculasan dengan tidak mematuhi perjanjian dan tanggung jawab.

Perhatian pada pentingnya peranan negara telah dicerminkan oleh tulisan ulama-ulama terkemuka sepanjang sejarah. Al-Mawardi misalnya, telah menyatakan bahwa keberadaan sebuah pemerintah yang efektif, sangat diperlukan untuk mencegah kezaliman dan pelanggaran. Sedangkan Ibn Taimiyah pun menekankan Islam dan negara mempunyai hubungan yang tidak dapat dipisahkan. Satu pihak tidak dapat menjalankan perannya dengan baik tanpa adanya negara yang memainkan peranan penting, dan negara mungkin akan terpuruk dalam pemerintahan yang tidak adil dan tirani tanpa pengaruh syari'ah. Demikian pula Baqir al-Sadr sebagaimana dikutip oleh Umer Chapra mengatakan bahwa intervensi pemerintah dalam ruang lingkup kehidupan perekonomian adalah penting dalam menjamin keselarasan dengan norma-norma Islam (Nasution: 2007, 189).

Syarat utama untuk menjamin sebuah sistem ekonomi pasar yang fair dan adil adalah perlunya suatu peran pemerintah yang sangat canggih yang merupakan kombinasi dari prinsip non-intervention. Dalam teori Adam Smith seperti yang dikutip oleh Mustafa Edwin bahwa peran bahkan campur tangan pemerintah tidak ditolak sama sekali atas dasar prinsip no harm, yaitu bahwa demi menegakkan prinsip keadilan no harm, pemerintah harus campur tangan. Jadi, bahkan sebaliknya, dalam situasi tertentu pemerintah justru dituntut untuk campur tangan. Dalam situasi seperti itu, pemerintah yang tidak ikut campur tangan justru akan dianggap tidak adil. Situasi seperti ini adalah situasi di mana ada pihak tertentu yang dilanggar hak dan kepentingannya atau yang dirugikan oleh pihak lain secara tidak sah.

Harus diyakini nilai konsep Islam tidak memberikan ruang intervensi dari pihak manapun untuk menentukan harga, kecuali dan hanya kecuali adanya kondisi darurat yang kemudian menuntut pihak-pihak tertentu untuk ambil bagian menentukan harga. Pengertian darurat di sini adalah pada dasarnya peranan pemerintah ditekan seminimal mungkin. Namun intervensi pemerintah sebagai pelaku usaha dapat dibenarkan hanyalah jika pasar tidak dalam keadaan sempurna, dalam arti ada kondisi-kondisi yang menghalangi kompitisi yang fair terjadi (market failure).

Berkaitan dengan penetapan harga, perjanjian penetapan harga merupakan salah satu bentuk perjanjian yang dilarang oleh Undang-undang 
Nomor 5 tahun 1999 tentang Larangan Praktek Monopoli dan Persaingan Usaha Tidak Sehat. Dalam prakteknya ada beberapa bentuk perjanjian penetapan harga, yaitu penetapan harga antara pelaku usaha (price fixing); penetapan harga yang berbeda terhadap barang dan atau jasa yang sama (diskriminasi harga); penetapan harga di bawah harga pasar dengan pelaku usaha lain (predatory price); dan penetapan harga jual kembali (resale price maintenance).

Penetapan harga antar pelaku usaha (price fixing) menurut ketentuan pasal 5 ayat (1) Undang-undang Nomor 5 tahun 1999, pelaku usaha dilarang mengadakan perjanjian dengan pelaku usaha pesaingnya guna menetapkan suatu harga tertentu atas suatu barang dan/atau jasa yang akan diperdagangkan pada pasar bersangkutan. Larangan muncul sebab perjanjian seperti itu akan meniadakan persaingan usaha diantara pelaku usaha yang mengadakan perjanjian tersebut. Oleh karena itu, hal ini dianggap per se illegal. Dalam pasal 5 ayat (1) dikatakan bahwa perjanjian penetapan harga dilarang tanpa melihat efek negatif dari perjanjian tersebut terhadap persaingan. Dengan kata lain, walaupun efek negatif terhadap persaingan usaha kecil, perjanjian price fixing tetap dilarang. Akan tetapi undang-undang memberikan perkecualian terhadap larangan membuat perjanjian tentang penetapan harga antar pelaku usaha ini, yaitu jika perjanjian penetapan harga tersebut dibuat: Dalam suatu usaha patungan (joint venture), atau; didasarkan pada undang-undang yang berlaku (Vide Pasal 5 ayat (2) Undang-undang Nomor 5 tahun 1999).

Dalam undang-undang tidak dijelaskan usaha patungan seperti apa yang bisa dikecualikan. Bila usaha patungan membuat collateral restraint, yakni perjanjian yang membatasi kompetisi dimasa datang antara para pihak, usaha ini bisa menghadapi tuntutan pelanggaran peraturan dibidang anti monopoli dan persaingan usaha tidak sehat. Dengan demikian tidak bisa dikatakan bahwa semua perjanjian dalam usaha patungan tidak akan merugikan persaingan. Perlu dibuatkan penjelasan lagi mengenai kriteria usaha patungan yang dapat dikecualikan.

Kemudian tentang Penetapan harga yang berbeda terhadap barang dan atau jasa yang sama (diskriminasi harga). Pembuatan perjanjian yang berisikan penetapan harga berbeda terhadap bar ang dan atau jasa yang sama dilarang oleh Pasal 6 Undang-undang Nomor 5 tahun 1999. Berdasarkan ketentuan 
pasal 6 tersebut, diskriminasi harga dilarang apabila pelaku usaha membuat suatu perjanjian dengan pelaku usaha lain yang mengakibatkan pembeli satu harus membayar harga yang tidak sama atau berbeda dengan harga yang harus dibayar oleh pembeli lain untuk barang dan/atau jasa yang sama, karena hal ini dapat menimbulkan persaingan usaha yang tidak sehat dikalangan pelaku usaha atau dapat merusak persaingan usaha. Dalam hal ini terdapat tiga jenis dan tingkatan strategis diskriminasi harga, dimana setiap tingkatan menuntut informasi yang berbeda mengenai konsumen, yaitu:

a. Diskriminasi harga sempurna, dimana produsen akan menetapkan harga yang berbeda untuk setiap konsumen. Dengan menerapkan strategi ini, produsen akan menyerap seluruh surplus konsumen, sehingga dapat mencapai laba yang paling tinggi.

b. Pada situasi dimana produsen tidak dapat mengidentifikasi maksimum harga yang dapat dikenakan untuk setiap konsumen, atau situasi dimana produsen tidak dapat melanjutkan struktur harga yang sama untuk tambahan unit penjualan, maka produsen dapat menetapkan strategi diskriminasi tingkat harga kedua, dimana produsen akan menerapkan sebagian dari surplus konsumen. Pembeli yang bersedia membeli barang lebih banyak diberikan harga per unit yang lebih murah. Strategi ini banyak dilakukan pada penjualan grosir atau pasar swalayan besar.

c. Bentuk terakhir diskiminasi harga umumnya diterapkan produsen yang mengetahui bahwa permintaan atas produk mereka beragam secara sistematik berdasarkan karakteristik konsumen dan kelompok demografis (Rachmadi Usman: 2004, 49-50).

Sedangkan kaitannya dengan penetapan harga di bawah harga pasar dengan pelaku usaha lain (predatory price), penetapan harga ini dilarang oleh pasal 7 Undang-Undang Nomor 5 tahun 1999. Pasal 7 menyatakan bahwa pelaku usaha dilarang membuat perjanjian dengan pelaku usaha pesaingnya untuk menetapkan harga di bawah pasar, yang dapat mengakibatkan terjadinya persaingan usaha tidak sehat. Pada satu sisi, penetapan harga di bawah biaya marginal akan menguntungkan konsumen dalam jangka pendek tetapi di pihak lain akan sangat merugikan pesaing (produsen lain). Strategi yang tidak sehat ini pada umumnya beralasan bahwa harga yang ditawarkan merupakan hasil kinerja peningkatan efisiensi perusahaan. Strategi ini akan 
menyebabkan produsen menyerap pangsa pasar yang lebih besar, yang dikarenakan berpindahnya konsumen pada penawaran harga yang lebih rendah. Pada jangka yang lebih panjang, produsen pelaku predatory pricing akan dapat bertindak sebagai monopolis.

Adapun kaitannya dengan penetapan harga jual kembali (resale price maintenance), sama halnya dengan penetapan harga di bawah harga pasar dengan pelaku usaha lain (predatory price). Penetapan harga jual kembali dilarang oleh Pasal 8 Undang-undang Nomor 5 tahun 1999. Berdasarkan ketentuan pasal 8 ini, pelaku usaha (supplier) dilarang membuat perjanjian dengan pelaku usaha lain (distributor) untuk menetapkan harga vertikal (resale price maintenance), dimana penerima barang atau jasa selaku distributornya tidak boleh menjual atau memasok kembali barang dan/atau jasa yang telah diterimanya dari suplier tersebut dengan harga yang lebih rendah daripada harga yang telah diperjanjikan sebelumnya diantara supplier dan distributor, sebab hal itu akan dapat menimbulkan persaingan usaha tidak sehat. Dari bunyi pasal 8 terlihat bahwa perjanjian penetapan harga vertikal hanya dilarang apabila dapat mengakibatkan terjadinya persaingan usaha tidak sehat.

Dalam teori ilmu hukum, larangan terhadap tindakan persaingan usaha tidak sihat pada garis besarnya dilakukan dengan menggunakan salah satu dari dua teori, yaitu doktrins Per Se dan doktrin Rule of Reason. Larangan yang bersifat Per $S e$ merupakan bentuk larangan yang tegas dalam rangka memberikan kepastian bagi para pelaku usaha dalam memaknai normanorma larangan dalam persaingan usaha. Dalam praktek, pengaturan ini berguna agar pelaku usaha sejak awal mengetahui rambu-rambu terhadap perbuatan apa saja yang dilarang dan harus dijauhkan dalam praktik usaha guna menghindari munculnya potensi resiko bisnis yang besar dikemudian hari sebagai akibat pelanggaran terhadap norma-norma larangan tersebut. Apabila pelaku usaha tidak dapat mengendalikan dirinya dan melanggar ketentuan hukum yang mengatur (Per Se Illegal), maka Komisi Pengawasan Persaingan Usaha cukup membuktinya bahwa telah terjadi pelanggaran. Pelanggaran terhadap larangan yang bersifat $\mathrm{Per} S e$, ancaman pidana pokoknya lebih rendah daripada pelanggaran terhadap larangan yang bersifat Rule of Reason (vide Pasal 48), (Johnny Ibrahim: 2007, 222-224). 
Doktrin Rule of Reason berasal dari tradisi comon law (case law). Dalam doktrin Rule of Reason, jika suatu kegiatan yang dilarang dilakukan oleh seorang pelaku usaha akan dilihat seberapa jauh efek negatifnya. Ciri-ciri pembeda terhadap larangan yang bersifat Rule of Reason adalah bentuk aturan yang menyebutkan adanya persyaratan tertentu yang harus terpenuhi sehingga memenuhi klasifikasi adanya potensi bagi terjadinya praktik monopoli atau praktik persaingan usaha. Perbuatan-perbuatan yang dimaksud jika terbukti merupakan perbuatan yang menghalangi persaingan (anti kompetitif) selain menghadapi sanksi administratif (Pasal 47), juga diancam sanksi pidana, baik pidana pokok (Pasal 48 ayat 1) maupun pidana tambahan (Pasal 49).

Pendekatan per se illegal dan rule of reason adalah konsep klasik dalam hukum persaingan usaha. Kedua pendekatan ini juga berlaku pada UU No. 5 Tahun 1999, sehingga ada bentuk perjanjian atau kegiatan yang per se, namun ada juga bentuk perjanjian atau kegiatan yang rule of reason.

Secara sederhana, kedua pendekatan itu dapat disandingkan dengan delik formal dan delik material. Pada delik formal, unsur-unsur pidananya sudah dianggap lengkap begitu perbuatannya itu selesai dilakukan, sehingga tidak perlu ada pembuktian lebih lanjut. Pada delik material, unsur-unsur itu belum lengkap jika syarat akibat perbuatan itu tidak tercakup di dalamnya. Tindak pidana pembunuhan (Pasal 338 KUHP) adalah contoh jenis delik material karena akibatnya harus berupa kehilangan nyawa. Jika belum ada korban yang mati, belum dapat disebut pembunuhan.

Pada hakikatnya, semua tindakan yang terlarang secara per se diasumsikan mengandung konsekuensi yang lebih berat dibandingkan dengan rule of reason. Misalnya, Pasal 5 Ayat (1) tentang perjanjian penetapan harga: "Pelaku usaha dilarang membuat perjanjian dengan pelaku usaha pesaingnya untuk menetapkan harga atas suatu barang dan atau jasa yang harus dibayar oleh konsumen atau pelanggan pada pasar bersangkutan yang sama." Pasal ini dimasukkan dalam kategori terlarang secara per se. 
Berdasarkan hal tersebut, maka dapat dipahami bahwa apapun alasannya, tindakan pelaku usaha yang mengarah pada kegiatan produksi atau pemasaran barang dan atau jasa yang dilakukan dengan cara yang tidak jujur, melawan hukum atau mengahambat persaingan usaha berarti telah melanggar undang-undang. Apabila itu semua diimplementasikan dengan baik, tentunya akan menciptakan kondisi pasar yang penuh dengan pelaku usaha yang baik, mendorong kegiatan pelaku usaha, memungkinkan pelaku usaha baru masuk pasar, dan efisiensi kegiatan pelaku usaha dapat ditingkatkan, dan harga akan seimbang.

\section{E. Penutup}

Persaingan usaha menurut hukum ekonomi Islam merupakan kompetisi yang diperbolehkan, asalkan persaingan usaha itu dilaksanakan secara sehat, akan tetapi apabila persaingan usaha yang dilaksanakan itu bersifat monopolistik dalam rangka mengambil keuntungan, maka ekonomi Islam melarangnya. Hal ini disebabkan karena ekonomi Islam memberikan garisan bahwa persaingan usaha harus dilakukan secara sehat (fair play) dengan prinsip kejujuran (honesty), keterbukaan (transparancy), dan keadilan (justice). Sedangkan menurut Undang-Undang No. 5 Tahun 1999, persaingan usaha merupakan persaingan yang diperbolehkan, akan tetapi apabila persaingan antar pelaku usaha dalam menjalankan kegiatan produksi dan atau pemasaran barang dan atau jasa yang dilakukan dengan cara tidak jujur atau melawan hukum atau menghambat persaingan usaha, maka menurut ketentuan Pasal 17 ayat (1) Undang-Undang No. 5 Tahun 1999, persaingan usaha tersebut dilarang.

Prospek penerapan UU No. 5 Tahun 1999 sebagai upaya pencegahan terhadap persaingan usaha di Indonesia yang bersifat monopolistik mengakibatkan harga kompetitif dengan kualitas terbaik, persaingan dapat memacu inovasi yang lebih baik, persaingan dapat mendorong mobilitas sosial, persaingan memiliki efisiensi produktif dan efisiensi alokatif, hukum yang kondusif bagi pelaksanaan persaingan usaha, dan stabilitas dan prediktabilitas. 


\section{REFERENSI}

Ad-Darimy, Sunan Ad-Darimy, Beirut: Darul Fikri, tt.

Ali, Atabik, dan Achmad Zuhdi Muhdlor, Kamus Kontemporer Arab Indonesia, Pon-Pes Krapyak : PT. Multi Karya Grafika, 1998.

al-Qasim, Yusuf, At-Ta'mil at-Tijariyyi fi Mijan asy-Syari'ah, Kairo: Dar anNahdhoh al-'Arabiyyah, 1986.

Antonio, M. Syafi'i, Bank Syariah dari Teori ke Praktek, Jakarta : Gema Insai Press, 2001.

Fuady, Munir, Hukum Anti Monopoli Menyongsing Era Persaingan Sehat, Bandung: PT. Citra Aditya Bakti, 1994.

Kantz, Michael dan Harveey S Rosen, Microeconomic, USA: Richard D. Irwin Inc, 1994.

Karim, Adiwarman A., Ekonomi Mikro Islami, Jakarta: Rajawali Pers, 2010, Cet. Ke-3.

Karim, Adiwarman A., Kajian Ekonomi Islam Kontemporer, Jakarta, TIII, 2003.

Kartika, Elsi Sari dan Advendi Simangunsong, Hukum dalam Ekonomi, Jakarta: PT. Gramedia Widiasarana Indonesia, 2007.

Kartono, Kartini, Pengantar Metodologi Riset Sosial,Bandung: Mandar Maju, 1996, Cet. Ke-VII.

KPPU, Undang-undang Nomor 5 Tahun 1999 tentang Larangan Praktik Monopoli dan Persaingan Usaha Tidak Sehat, Jakarta, 2008.

Marzuki, Peter Mahmud, Telaah Filosofi terhadap Undang-Undang Larangan Praktek Monopoli dan Persaingan Usaha Tidak Sehat Dalam Kaitannya Dengan Konstitusi Republik Indonesia, Surabaya: Majalah Yuridika, Fakultas Hukum Universitas Erlangga, 2001.

Maulana, Agus, Pengantar Mikro Ekonomi, Jakarta: Bina Rupa Aksara, 2000, Jilid II. 
Maya Meilia dan Darania Anisa: Persaingan Usaha Tidak Sehat di Indonesia Menurut.....

Muhammad, Ekonomi Mikro dalam Perspektif Islam, Yogyakarta: BPFE, 2004, Cet. Ke-1.

Munawir, Ahmad Warson, Kamus al-Munawwir, Yogyakarta: Unit Pengadaan Buku Pondok Pesantren al-Munawwir, 1994.

Nasution, Mustafa Edwin, dkk., Pengenalan Eksklusif Ekonomi Islam, Jakarta: Kencana, 2007.

Trubeck, David M., "Toward a Social Theory of Law: An Essay on the Study of Law an Development," The Yale Law Journal, Vol. 82, No. 1, 1972. 